\title{
Evaluation of Occult Hepatitis B Infection in Individuals with Chronic Hepatitis C Before Treatment with Oral Direct-Acting Antivirals
}

\author{
Nathalia Alves Araujo de Almeida ${ }^{1}$, José J. Barros ${ }^{1}$, Catarina Goes de Santana ${ }^{2}$, Natalia Spitz ${ }^{1}$, Leticia \\ Bomfim Campos ${ }^{1}$, Marcia Amendola Pires ${ }^{2}$, Carlos Eduardo Brandao Mello $^{2}$ and Vanessa Salete de \\ Paula $^{1, *}$ \\ ${ }^{1}$ Laboratory of Molecular Virology, Oswaldo Cruz Institute/Fiocruz, Rio de Janeiro, Brazi \\ ${ }^{2}$ Gaffrée and Guinle Universitary Hospital, Ambulatory of Liver Disease, Rio de Janeiro State Federal University/UniRio, Rio de Janeiro, Brazil \\ "Corresponding author: Laboratory of Molecular Virology, Oswaldo Cruz Institute/Fiocruz, CEP 21040-90o Rio de Janeiro, Brazil. Email: vdepaula.fiocruz@gmail.com
}

Received 2019 April 15; Revised 2019 September 20; Accepted 2019 September 27.

\begin{abstract}
Occult hepatitis B virus infection (OBI) is one of the most challenging entities in the field of viral hepatitis. The virological and clinical relevance of $\mathrm{OBI}$ in patients treated with novel direct-acting antivirals (DAA) for hepatitis C virus (HCV) infections is currently a topic of hot debate. In cases where hepatitis B surface antigen (HBsAg) is not detected, DAA treatment is often initiated without examining for the presence of hepatitis B virus (HBV) DNA. In this study, the incidence of OBI was investigated in $114 \mathrm{HCV}$ patients prior to application of DAAs who did not respond to pegylated interferon and ribavirin (PEG-INF and RBV) treatment. Serum samples were screened for HBV serological markers (antibody to hepatitis B core antigen [anti-HBc] and HBsAg). Samples positive for antiHBc without HBsAg were further examined via real-time PCR (qPCR), nested PCR and S-gene mutational analyses. Overall, anti-HBc was detected in $37.7 \%$ chronic HCV patients and $2.6 \%$ had OBI with a baseline HBV DNA viral load < $2000 \mathrm{IU} / \mathrm{mL}$ before DAA therapy. One patient was identified as HBV genotype A1 without mutations in surface protein. Our collective data highlight the importance of clinicians being aware of potential anti-HBc positivity in patients with hepatitis $\mathrm{C}$ and the issues surrounding OBI screening before initiation of treatment with novel DAAs.
\end{abstract}

Keywords: Hepatitis C, Occult Hepatitis B, DAA Treatment

\section{Background}

Hepatitis B virus (HBV) infection remains a global public health problem, even following the development of an effective vaccine. Brazil is classified as a region with low to intermediate prevalence of HBV surface antigen (HBsAg) carriers ( $<2 \%$ ), including areas of high HBV endemicity ( $>$ $8 \%$ ) (1). Occult HBV infection (OBI) is the most challenging issue in the field of viral hepatitis, with its virological and clinical relevance in patients undergoing treatment for hepatitis $\mathrm{C}$ being a hot topic of debate at present. Occult $\mathrm{HBV}$ infection is determined by the absence of HBsAg and presence of HBV DNA in liver or serum of infected patients $(2,3)$ and classified as: (1) seropositive OBI (positive for antibody to hepatitis B core antigen [anti-HBc] and/or antibody to hepatitis B surface antigen [anti-HBs]), (2) seronegative OBI (negative for anti-HBc and anti-HBs), and (3) "false" OBI due to the presence of $\mathrm{HBV}$ variants with mutations in the $S$ gene (escape mutants) producing modified HBsAg that are not recognized by some or all commercially available detection assays $(2,3)$. The frequency of OBI in Brazil ranges from $0 \%$ to $24 \%$ (4-9) and has significant relevance in a clinical context, since it can lead to the development of severe hepatic diseases, such as cirrhosis and hepatocellular carcinoma, and eventually, death. Viral factors of OBI induction may be associated with mutations, especially in the $S$ protein, and co-infection with other viruses such as hepatitis $C$ virus (HCV) (10). Reactivation of HBV has been reported in patients with chronic HCV or resolved HBV infection under treatment with newer direct-acting antivirals (DAA) (11), resulting in fulminant hepatitis, liver failure and in some cases, death. According to the Brazilian Clinical Protocol and Therapeutic Guidelines for Hepatitis $C$ and Coinfections, individuals detected with HBsAg prior to initiation of DAA are recommended HBV therapy to prevent reactivation owing to hepatitis $C$ treatment. However, in cases where HBsAg is not detected, treatment with DAAs is released without examining for the presence of HBV-DNA (12). Although hepatitis B reactivation in patients is known to occur during hepatitis $\mathrm{C}$ treatment with direct-acting antivirals, only a few cases have been described to date. 
Moreover, no data are available on OBI/HCV coinfection in patients scheduled for DAA treatment in Brazil.

\section{Objectives}

In this study, we evaluated the prevalence of anti-HBc and examined for OBI via real-time and nested PCR analyses in patients with chronic hepatitis $C$ before commencement of DAA therapy. We additionally investigated the presence of mutations in the $S$ gene associated with cases of false OBI.

\section{Methods}

Our retrospective cross-sectional study was conducted in patients prior to commencement of DAA treatment who had attended the Outpatient Clinic of Liver Disease at the Gaffrée and Guinle University Hospital (Rio de Janeiro, Brazil) from January to December 2018. Clinical, demographic as well as HBV and HCV treatment data were acquired from medical records. Serum samples were collected from a cohort of 114 consecutive HCV patients. The patients included for study had failed pegylated interferon and ribavirin (PEG-INF and RBV) therapy. All serum samples were HCV RNA-positive and examined for total HBc and HBsAg via immunoenzymatic assays (EIA). Samples positive for anti-HBc with no HBsAg were further examined using real-time PCR (qPCR) and nested PCR (13). The HBV DNA was additionally sequenced for genotyping and detection of $S$ gene mutations. Notably, the presence of OBI was correlated with aspartate aminotransferase (AST) and alanine aminotransferase (ALT) levels.

\section{Results and Discussion}

In a serological test, 37.7\% (43/114) patients were identified as positive for anti-HBc, consistent with a previous report of antibody prevalence of up to $35 \%$ in HCVinfected populations (11). Occult HBV infection was detected in three $(2.6 \%)$ male patients with a mean age of 69.3 years classified as HCV genotypes 1 and 3. The patients had received treatment with pegylated interferon (80 mcg) and ribavirin (1.0 g per day) for 24 weeks without HCV clearance. No patients developed ALT and AST flareups and all were anti-HB-positive, with viral loads ranging from 207.14 to $1547 \mathrm{IU} / \mathrm{mL}\left(1.16 \times 10^{3}\right.$ to $8.51 \times 10^{4}$ copies $/ \mathrm{mL}$ ) (Table 1 ). Patients with the highest viral loads were positive for S-region amplification (GenBank accession number MK360178) via nested-polymerase chain reaction (nested-PCR) and HBV in these cases was classified as genotype A1 (Figure 1), the most prevalent in Brazil (14).
Deletion or insertion of nucleotides in the $S$ region was not associated with non-detection of HBsAg with commercial kits or non-expression of HBV surface antigen. The patient had chronic active hepatitis $\mathrm{C}$, grade 4 , with cirrhosis (F4, $38.5 \mathrm{kPa}$; fibroscan). All patients were re-treated with sofosbuvir (400 mg)+ daclatasvir (60 mg) + ribavirin (1.0 gram), following which HCV remained undetectable. The presence of HBV DNA has been reported among patients with hepatitis $C$ treated with DAAs. However, in patients with resolved (anti-HBs and anti-HBc) HBV infections, no HBV reactivation-related hepatitis is documented (3). In the current study, all three patients had HBV DNA viral loads $<2000 \mathrm{IU} / \mathrm{mL}$ before DAA therapy. A systematic review and meta-analysis published in 2018 provided evidence of significantly lower relative risk of HBV reactivation-related hepatitis in patients with HBV DNA below the lower limit of quantification at baseline than those with quantifiable HBV DNA (11).

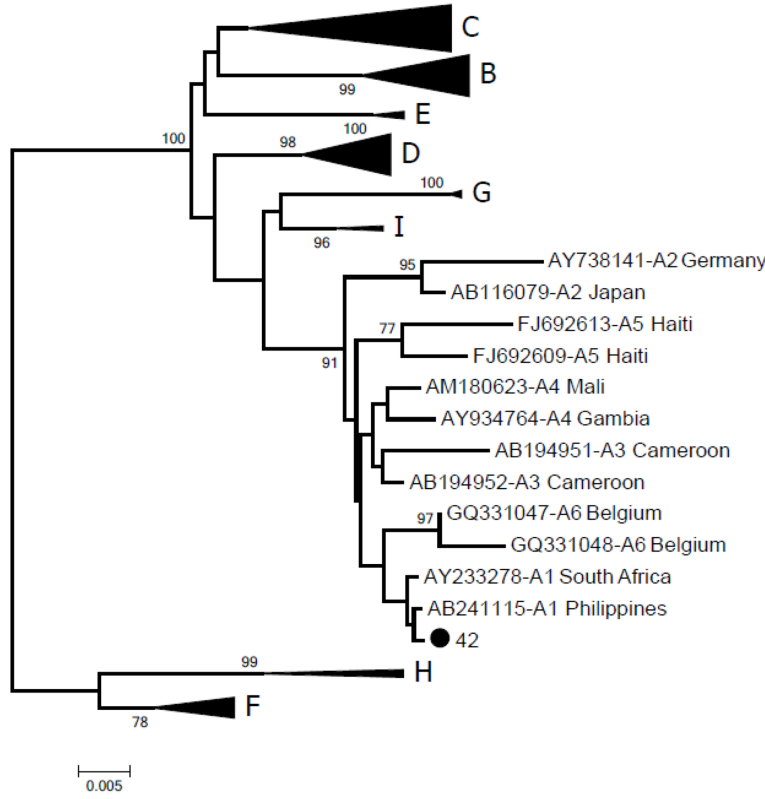

Figure 1. Phylogenetic tree of the HBV S-gene inferred using the neighbor-joining method. Values in the branches indicate the percentage of 1000 bootstrap replicates supporting the group. The sequence generated in this study is represented by a black dot (GenBank accession number MK360178). Reference sequences are indicated by their accession number, followed by subgenotype and geographical origin.

Since the patient populations at risk for HBV reactivation and management options are currently unclear, these cases clearly highlight the importance of HBV DNA testing prior to initiation of DAA therapy. Several studies assessing the prevalence of OBI in patients with chronic HCV infection have reported dissimilar rates of HBV DNA positivity, which may be explained by differences in the preva- 


\begin{tabular}{|c|c|c|c|c|c|c|c|}
\hline ID & Copies/mL & $\mathrm{IU} / \mathbf{m L}$ & ALT & AST & HCV Genotype & HBV Genotype & Fibrosis Stage \\
\hline 001 & $1.16 \times 10^{3}$ & 207.14 & 59 & 102 & 1a & ND & F4 \\
\hline 042 & $8.5 \times 10^{4}$ & 1517.8 & 87 & 137 & 3a & A1 & F4 \\
\hline 268 & $1.29 \times 10^{4}$ & 230.357 & 74 & 100 & $1 \mathrm{~b}$ & ND & $\mathrm{F} 4$ \\
\hline
\end{tabular}

Abbreviation: ND, not determined

lence of HBV infection in different geographic regions, detection limits of HBV DNA assays and/or the biological material analyzed (liver tissue or serum) (9). Low levels of anti-HBs and decrease to $<12 \mathrm{mIU} \mathrm{mL}$ after treatment are significant risk factors for HBV reactivation or reappearance (15). We observed no differences in anti-HBs levels before and after treatment with DAAs and the small elevation of ALT/AST observed in patients with OBI HBV reactivation could be prevented with pretreatment screening and prophylactic treatment where necessary (16). It can occur spontaneously but is triggered by various factors and often transient without clinical symptoms in most cases other than causing a hepatitis flare. Moreover, $\mathrm{HBV}$ reactivation may occur regardless of HCV genotype and type of DAA regimen (16).

While OBI and risk of HBV reactivation are relatively rare, it is important to account for the possibility that in some instances, subjects undergoing new treatments are infected with HBV viral DNA, since HCV and previous treatments can inhibit HBV replication and influence evolution of the disease. Based on findings from the current study, we recommend that clinicians should be aware of possible anti-HBc positivity in patients and examine for hepatitis B infection along with the issues surrounding OBI screening before initiating treatment with novel DAAs. To our knowledge, this is the first study in Brazil to focus on OBI in individuals with chronic hepatitis $C$ before DAA treatment. Our collective results should contribute to formulating effective therapeutic guidelines for treatment of hepatitis $\mathrm{C}$ and concomitant infections and support routine evaluation of $\mathrm{OBI} / \mathrm{HCV}$ coinfections before and during treatment with DAAs.

\section{Footnotes}

Conflict of Interests: The authors declare that they have no conflicts of interest.

Ethical Approval: The study protocol was approved by the Research Ethics Committee of the Institute Oswaldo Cruz (CAAE 34246914.4.1001.5248 number 2.927.747/18).

Funding/Support: This work was supported by Coordination for the Improvement of Higher Education Personnel
(CAPES) and the Oswaldo Cruz Foundation.

\section{References}

1. World Health Organization. Global hepatitis report. World Health Organization; 2017. 83 p.

2. Raimondo G, Allain JP, Brunetto MR, Buendia MA, Chen DS, Colombo $M$, et al. Statements from the Taormina expert meeting on occult hepatitis B virus infection. J Hepatol. 2008;49(4):652-7.

3. Cheng HR, Kao JH, Wu HL, Chen TC, Tseng TC, Liu CH, et al. Clinical and virological features of occult hepatitis B in patients with HBsAg seroclearance post-treatment or spontaneously. Liver Int. 2014;34(6):e71-9. doi: 10.1111/liv.12324. [PubMed: 24119014].

4. Alencar RS, Gomes MM, Sitnik R, Pinho JR, Malta FM, Mello IM, et al. Low occurrence of occult hepatitis B virus infection and high frequency of hepatitis $C$ virus genotype 3 in hepatocellular carcinoma in Brazil. Braz J Med Biol Res. 2008;41(3):235-40. doi: 10.1590/s0100879x2006005000197. [PubMed: 18097499].

5. Motta JS, Mello FC, Lago BV, Perez RM, Gomes SA, Figueiredo FF. Occult hepatitis $B$ virus infection and lamivudine-resistant mutations in isolates from renal patients undergoing hemodialysis. J Gastroenterol Hepatol. 2010;25(1):101-6. doi: 10.1111/j.1440-1746.2009.05972.x. [PubMed: 19817965].

6. Branco F, Mattos AA, Coral GP, Vanderborght B, Santos DE, Franca $P$, et al. Occult hepatitis $B$ virus infection in patients with chronic liver disease due to hepatitis $C$ virus and hepatocellular carcinoma in Brazil. Arq Gastroenterol. 2007;44(1):58-63. doi: 10.1590/s000428032007000100013. [PubMed:17639185].

7. Fontenele AM, Gainer JB, da Silva ED, Cruz Santos MD, Salgado JV, Salgado Filho N, et al. Occult hepatitis B among patients with chronic renal failure on hemodialysis from a capital city in northeast Brazil. Hemodial Int. 2015;19(3):353-9. doi: 10.1111/hdi.12285. [PubMed: 25733070].

8. Peres AA, Dias EA, Chesky M, Alvares-da-Silva MR, Jobim LF, Goncalves LF, et al. Occult hepatitis B in renal transplant patients. Transpl Infect Dis. 2005;7(2):51-6. doi: 10.1111/j.1399-3062.2005.00091.x. [PubMed: 16150090].

9. Rosa AS, Araujo OC, Savassi-Ribas F, Fernandes CA, Coelho HS, Niel $\mathrm{C}$, et al. Prevalence of occult hepatitis B virus infection and Torque teno virus infection and their association with hepatocellular carcinoma in chronic hepatitis C patients. Virus Res. 2017;242:166-72. doi: 10.1016/j.virusres.2017.09.022. [PubMed: 28966070].

10. Zhu HL, Li X, Li J, Zhang ZH. Genetic variation of occult hepatitis B virus infection. World J Gastroenterol. 2016;22(13):3531-46. doi: 10.3748/wjg.v22.i13.3531. [PubMed: 27053845]. [PubMed Central: PMC4814639].

11. Mucke MM, Backus LI, Mucke VT, Coppola N, Preda CM, Yeh ML, et al. Hepatitis B virus reactivation during direct-acting antiviral therapy for hepatitis C: A systematic review and meta-analysis. Lancet Gastroenterol Hepatol. 2018;3(3):172-80. doi: 10.1016/S2468-1253(18)300025. [PubMed: 29371017].

12. Ministry of Health. Protocolo clínico e diretrizes terapêticas para hepatite C e coinfecções. Brasilia: Ministry of Health; 2018. 
13. Portilho MM, Mendonca A, Bezerra CS, do Espirito-Santo MP, de Paula VS, Nabuco LC, et al. Usefulness of in-house real time PCR for HBV DNA quantification in serum and oral fluid samples. $J$ Virol Methods. 2018;256:100-6. doi: 10.1016/j.jviromet.2018.03.001. [PubMed: 29514044].

14. Lampe E, Mello FCA, do Espirito-Santo MP, Oliveira CMC, Bertolini DA, Goncales NSL, et al. Nationwide overview of the distribution of hepatitis B virus genotypes in Brazil: A 1000-sample multicentre study. J Gen Virol. 2017;98(6):1389-98. doi: 10.1099/jgv.0.000789. [PubMed: 28631602]. [PubMed Central: PMC5962896].
15. Kawagishi N, Suda G, Onozawa M, Kimura M, Maehara O, Ito J, et al. Hepatitis B virus reactivation during hepatitis C directacting antiviral therapy in patients with previous HBV infection. $J$ Hepatol. 2017;67(5):1106-8. doi: 10.1016/j.jhep.2017.04.008. [PubMed: 28438688].

16. Aggeletopoulou I, Konstantakis C, Manolakopoulos S, Triantos C. Risk of hepatitis $\mathrm{B}$ reactivation in patients treated with direct-acting antivirals for hepatitis C. World J Gastroenterol. 2017;23(24):4317-23. doi: 10.3748/wjg.v23.i24.4317. [PubMed: 28706414]. [PubMed Central: PMC5487495]. 